\title{
Public Consumption and Income in the Long Run: A Panel Data Study for Central African Countries
}

\author{
Impawe Augustin $^{1}$ \\ ${ }^{1}$ International Center of Research in Economics and Management for Development, Omar Bongo University, \\ Gabon
}

Correspondence: Impawe Augustin, International Center of Research in Economics and Management for Development, Omar Bongo University, Gabon. Tel: 241-0794-0515. E-mail: impaweaugustin@yahoo.fr

Received: March 18, 2019

Accepted: May 7, 2019

Online Published: May 12, 2019

doi:10.5539/ijef.v11n6p101

URL: https://doi.org/10.5539/ijef.v11n6p101

\begin{abstract}
This article examines panel cointegration methods to study the long-run effect of public consumption on the real output of 10 Central African economies (ECCAS: CEMAC + 4) from 1990 to 2016. We integrate the investment in cointegration regression and take into account the transverse dependence in a panel data parameter. The results indicate on average that public consumption expenditure has a negative impact on long-term real GDP. Conversely, investment has a positive effect on income. Overall, the results show that a decrease in public consumption in the fiscal adjustment process has no effect on the growth of these economies.
\end{abstract}

Keywords: panel cointegration, government consumption, income, fiscal adjustment, ECCAS, CEMAC

\section{Introduction}

Since 2013, the ratio of public debt to GDP has increased in sub-Saharan African economies and now exceeds 50\% of GDP in most countries. The indebtedness of low-income countries or those facing a high risk of debt distress has risen from 7 in 2013 to 12 in 2016. Contributing factors include a widening of fiscal deficits, slow growth, falling prices of commodities and exchange rate depreciations in some countries. To this end, these countries are seeing an increase in consumer spending with adverse effects on private investment, economic growth and the current account. Therefore, government authorities should focus on structural reforms to address the obstacles to economic growth in Central African economies. In fact, over the past five years, these economies have seen a decline in government revenues. According to the IMF (2019), this decline is due to lower oil revenues (which decreased by 12.2 percentage points of GDP over this period, from $18.2 \%$ of GDP in 2012 to $5.9 \%$ in 2017 in the countries of CEMAC). Public debt has increased in most economies, particularly in the Central African Economic and Monetary Community (CEMAC), by $20.7 \%$ of GDP at the end of 2012, compared to $53.6 \%$ of GDP at the end of 2017. Thus, in most of these countries, economic performance remains dependent on government spending, debt levels and rising debt service costs. However, the economic situation in Central Africa remains difficult. In order to take into account the development needs of these countries, policymakers face additional challenges in developing and implementing policies that can reduce debt while minimizing long-term costs to the economy (Note 1). While the literature focuses primarily on the short term, it seems appropriate to explain the long-run effect of fiscal adjustment on the real output of Central African economies.

Empirically, many studies have examined the relationship of the fiscal adjustment effect to the real income of advanced economies. Research has therefore examined this relationship in many ways that have both short- and long-term effects on growth and the impact on growth of the fiscal policy response to other macroeconomic variables (see Gupta et al., 2005; DeLong \& Summers, 2012; Baum et al., 2012; Ilzetzki et al., 2013; Auerbach \& Gorodnichenko, 2013a and 2013b; Blanchard \& Leigh, 2013; Batini, 2014; Dell'Erba et al., 2014; Mineshima et al., 2014; Abiad et al., 2016; Arizala et al., 2017; and François \& Keinsley, 2019).

Yet, no study has assessed the long-term impact of fiscal policy's impact on real GDP in the context of Central African economies. Therefore, using heterogeneous panel cointegration techniques in ECCAS countries Economic Community of Central African States (CEMAC + 4) (1990-2016), the paper examines the long-term average effect of public consumption on revenues. Although the robustness of this cointegration approach with respect to endogeneity and omitted variables, we introduce investment in cointegration regression as it is one of the main determinants of long-term income. Taking investment into account captures policy information. To 
provide coefficient estimates, we use the Pedroni panel DOLS (Ordinary Least Squares Dynamics) estimator (2001b, a). This estimator takes into account serial correlation, small sample and endogeneity problems.

The rest of the article is organized as follows: Section 2 outlines the methodology, the variables, the method and the empirical results. Section 3 concludes the study.

\section{Econometric Strategy and Results}

This article adopts a cointegration regression including income, public consumption, and investment to assess the long-run effect of public consumption on income. Our starting point is the following model

$$
Y_{i t}=\varphi_{i}+\theta_{i} t+\delta_{1} G_{i t}+\delta_{2} K_{i t}+\zeta_{i t}
$$

With $Y_{i t}$ the logarithm of real GDP; $G_{i t}$ is the government consumption as percent of GDP; $K_{i t}$ investment as percent of GDP; $\delta_{1}$ and $\delta_{2}$ the coefficients to be estimated, $\varphi_{i}$ and $\theta_{i}$ the constant term and linear time trends; $i$ and $t$ respectively countries and time period. Real GDP is measured at 2010 constant prices; government consumption correspond to the general government final consumption expenditure as percent of GDP. Total investment is the gross fixed capital formation as percent of GDP. The data come from World Development Indicators 2018 database. The availability of data allowed the 1990-2016 period to be used for the empirical analysis. Table 1 presents the descriptive statistics of the variables.

Table 1. Descriptive statistics

\begin{tabular}{lccc}
\hline Variables & Income (in log) & Public consumption & Investment \\
\hline Mean & 22.732 & 14.683 & 25.552 \\
Median & 23.071 & 13.323 & 20.899 \\
Maximum & 25.367 & 59.722 & 219.069 \\
Minimum & 19.184 & 2.057 & 0.000 \\
Std. Dev. & 1.215 & 8.202 & 28.594 \\
Skewness & -0.320 & 2.240 & 4.173 \\
Kurtosis & 2.698 & 10.617 & 23.313 \\
Jarque-Bera & 5.633 & 878.613 & 5425.634 \\
Probability & 0.059 & 0.000 & 0.000 \\
Observations & 270 & 270 & 270 \\
& \multicolumn{2}{c}{ Central African Republic, Cameroon, Chad, Congo Republic, Equatorial } \\
Countries list ECCAS & CEMAC & Angola, Burundi, Rwanda Congo Democratic Republic \\
\hline
\end{tabular}

\subsection{Background Testing}

The long-term survey implies that the permanent change in public consumption as a percentage of GDP and investment as a percentage of GDP is linked to permanent changes in the logarithm of GDP. Then we continue with the unit root test for each series and test the cointegration relationship between real income (Yit), public consumption (Git) and investment (Kit).

\subsubsection{Panel Unit Roots Tests}

First of all, we establish the stationarity of the variables of interest. For that, we apply Im et al. (2003, hereafter IPS) panel unit root test based on the Augmented Dickey-Fuller (ADF) regression for the individual cross-section unit in the panel. Moreover, the occurrence of common shocks or spillovers effects among cross-section unit, may lead to the fact that the disturbance terms $\zeta_{i t}$ are not independent. For this purpose, the IPS test may lead to misleading inferences. Thus, we use the cross-scaled IPS test (CIPS) of Pesaran (2007). CIPS eliminates cross sectional dependence by increasing ADF regression with section averages cross-section of shifted levels and first differences of individual series (see e.g. Herzer \& Grimm, 2012; Baltagi \& Pesaran, 2007, for second-generation unit root tests).

For these two tests, the null hypothesis is the unit root (process of the individual root). The variables are specified, including intercept and including intercept and trend. The results of the unit root test (see Table 2) show that the null hypothesis is not rejected for the level variables. On the other hand, the tests reject the null hypothesis for the first differentiated variables. Therefore, we can argue that each variable in Eq (1) is integrated of order one, that is, I (1). 
Table 2. Panel unit root tests

\begin{tabular}{lll}
\hline Variables & IPS statistics & CIPS statistics \\
\hline Levels & & \\
Real Income & -1.1108 & -2.278 \\
Public Consumption & -0.708 & -2.474 \\
Total Investment & -1.114 & -2.648 \\
First Difference & & \\
Real Income & $-3.548 * * *$ & $-3.304 * * *$ \\
Public Consumption & $-9.318^{* * *}$ & $-4.448^{* * *}$ \\
Total Investment & $-7.351^{* * *}$ & $-4.255^{* * *}$ \\
\hline
\end{tabular}

Note. For the level data, we allow for both individual country effects and country-specific time trends. One lag was selected to adjust for autocorrelation. $* * *, * *$ and $*$ denote a rejection of the null hypothesis of no cointegration at the $1 \%, 5 \%, 10 \%$ level respectively.

\subsubsection{Cointegration Analysis}

Then, to verify the long-term relationship between the variables, we perform four cointegration tests, namely Kao (1999), Pedroni (1999, 2004), Westerlund (2005) and Fisher statistic of Maddala and Wu (1999). These tests combine derived statistics for each panel country, leading to a test with a higher power. Regarding the non-cointegration zero test in heterogeneous panels, the Pedroni test recommends seven statistics grouped into two groups ("in-dimension" panel and "between-size" panel tests). The "internal dimension" (panel tests) is based on four test statistics, panel ADF statistics, panel PP statistics, panel v statistics, and panel $\rho$ statistics. The "dimension between" (group tests) is based on three test statistics: ADF group statistic, PP statistic and $\rho$-statistical group. The application of the Pedroni test offers an additional advantage because the form in which the cross-sectional units and the time series data are grouped allows for greater flexibility in the presence of heterogeneity from one country to another for the cointegrated variables. In the spirit of Engel-Granger's two-step procedure, Kao (1999) defines an ADF test statistic implying homogeneity on panel units. On the other hand, Westerlund (2005) constructs a test statistic in the form of a ratio of variances (VR) in the background of Phillips and Ouliaris (1990) and Breitung (2002). This test does not require modeling or serial correlation adaptation; The VR test also checks for the absence of cointegration by looking for the presence of a unit root in the residuals. Finally, the Fisher statistic of Maddala and Wu (1999) follows a $\chi 2$ distribution with $2 \times \mathrm{N}$ degrees of freedom.

With respect to the cointegration techniques performed (Pedroni, Fisher, Kao and Westerlund) under the null hypothesis of "non cointegration", remarkable results are shown in Table 3. The panel tests "in the dimension" reject the null hypothesis of non-cointegration except for the $\rho$-statistical panel test. On the contrary, group tests "between dimensions" do not reject the null hypothesis. Looking at Kao's residual cointegration test, the null hypothesis is rejected; these results are corroborated by the results of the Westerlund VR cointegration test and Fisher's 2 statistic, which shows the existence of at least one cointegrating vector (Note 2).

Table 3. Panel cointegration tests

\begin{tabular}{llll}
\hline & Cointegration rank & \\
\hline & $\mathrm{r}=0$ & $\mathrm{r}=1$ & $\mathrm{r}=2$ \\
Fisher statistics & $102.8^{* * *}$ & $41.21^{* * *}$ & 16.21 \\
Kao test & & $-2.156^{* * *}$ & \\
Panel v-Statistic & & $5.913^{* * *}$ & \\
Panel $\rho$-Statistic & & 0.364 \\
Panel PP-Statistic & & $-1.989^{* *}$ \\
Panel ADF-Statistic & & $-2.921^{* * *}$ \\
Group rho-Statistic & & 2.413 \\
Group PP-Statistic & & 0.188 \\
Group ADF-Statistic & -0.555 \\
Westerlund vr-Statistic & $3.636^{* * *}$ \\
\hline
\end{tabular}

Note. The Fisher statistic is distributed as $\chi^{2}$ with $2 \times N$ degrees of freedom. Fisher statistic is derived from trace test. The number of lags was determined by the Akaike criterion with a maximum of two lags. $* * *, * *$ and $*$ denote a rejection of the null hypothesis of no cointegration at the $1 \%, 5 \%, 10 \%$ level respectively.

\subsection{Panel DOLS Estimation}

Since variables are primarily stationary and cointegrated differences, we focus on the long-run relationship 
between government consumption and income. It is well established that investment is considered one of the main determinants of economic growth; we join him in estimating the cointegrating relation of income to public consumption and investment. We use the Pedroni (2001b, a) estimator DOLS (dynamic least squares dynamics between groups of means between groups of means). The specific specification of the model is as follows:

$$
Y_{i t}=\varphi_{i}+\theta_{i} t+\delta_{1} G_{i t}+\delta_{2} K_{i t}+\sum_{j=-p_{i}}^{p_{i}} \Xi_{1 j} \Delta G_{i t-j}+\sum_{j=-p_{i}}^{p_{i}} \Xi_{2 i j} \Delta K_{i t-j}+\zeta_{i t}
$$

With $\Xi_{1 i j}$ and $\Xi_{2 i j}$ are lead and delay difference coefficients that account for the potential serial correlation and endogeneity of the regressors. The advantage of the DOLS approach is that it offers unbiased estimates of co-integrated series, even in cases of evidence of endogeneity. For illustration, since public consumption can respond to income changes cyclically, a problem of potential endogeneity obviously arises. The group-based DOLS estimator, which is super coherent under cointegration and robust against any omitted variable, is computed as follows:

$$
\text { 鳘 }=\frac{1}{N} \sum_{i=1}^{N} \beta_{m i}
$$

where $m=1,2$ and $\hat{\beta}_{m i}$ is the conventional DOLS estimator of the time series applied to the $i$ th panel country.

The DOLS method is applied to degraded data in order to address the cross-dependence caused by current shocks and / or contagion effects between countries. Thus, in lieu of $Y_{i t}, G_{i t}$, and $K_{i t}$, we use $\tilde{Y}_{i t}, \tilde{G}_{i t}$, and $\tilde{K}_{i t}$, such that

$$
\begin{aligned}
& \tilde{Y}_{i t}=Y_{i t}-\bar{Y}_{i t}, \text { where } \bar{Y}_{i t}=\frac{1}{N} \sum_{i=1}^{N} Y_{i t} \\
& \tilde{G}_{i t}=G_{i t}-\bar{G}_{i t}, \text { where } \bar{G}_{i t}=\frac{1}{N} \sum_{i=1}^{N} G_{i t}
\end{aligned}
$$

and

$\tilde{K}_{i t}=K_{i t}-\bar{K}_{i t}$, where $\bar{K}_{i t}=\frac{1}{N} \sum_{i=1}^{N} K_{i t}$.

In Table 4, we summarize the results of the cointegration regression for ECCAS - full panel. We report results for two types of data: first, unadjusted data that imply cross-country independence; second, degraded data, which deals with shocks and common impacts. Unadjusted results suggest that the impact of public consumption on real output is negative, although not statistically significant. Meanwhile, in the case of degraded data, the public consumption coefficient is negative and statistically significant. This indicates that a one percentage point cut in public consumption would result in an increase in real output of 0.0123 percentage points. Conversely, the total investment coefficient is always positive and significant in both data treatments.

Table 4. DOLS estimates of the coefficient on public consumption and investment

\begin{tabular}{lll}
\hline ECCAS & Public Consumption & Investment \\
Demeaned data & $-0.012^{*}$ & $0.008^{* * *}$ \\
& $(-1.867)$ & $(2.743)$ \\
Unadjusted data & -0.001 & $0.017^{* * *}$ \\
& $(-0.171)$ & $(4.942)$ \\
CEMAC & & \\
Demeaned data & $-0.020^{*}$ & 0.005 \\
& $(-1.935)$ & $(1.063)$ \\
Unadjusted data & $-0.018^{* *}$ & 0.001 \\
& $(-2.080)$ & $(0.244)$ \\
\hline
\end{tabular}

Note. he dependent variable is $\mathrm{y}_{\mathrm{it}}$. t-statistics in parentheses. The number of leads and lags in the individual DOLS regressions was determined by the Akaike criterion with a maximum of two lags. ***,**** indicate significance at 1,5 and 10 percent level. 
Given that the ten countries in our panel adopted include six countries in the CEMAC zone, we perform a sensitivity analysis by re-estimating the DOLS regression in the equation (2) to determine if the observed negative income-government relationship is valid for this group. Table 4 shows that the effect of public consumption on real income across CEMAC remains systematically negative and significant. Specifically, findings from degraded data (and unadjusted data) indicate that a $1 \%$ increase in government consumption decreases real GDP by 0.0207 (and 0.0186) percentage points in the CEMAC long term. In addition, the total investment coefficient is positive but not significant for both data processing; this means that the positive effect observed throughout the panel is fed by non-CEMAC countries.

\section{Final Remarks}

This paper explore the effect of public consumption spending on real output of Central African economies over the period 1990-2016. Typically, we examine how output react to changes in fiscal policy in these economies. By using heterogeneous panel cointegration approaches, we investigate the long-run effect of public consumption on revenue in 10 ECCAS (CEMAC+4) countries. The results suggest that, keeping investment constant, reducing government consumption is a suitable approach for restraining long-term costs in these economies. Specially, we note expansionary effects of this policy when we deal with the cross-country dependence (demeaned data). This reveals that expansionary effect is also a long run phenomenon that is not limited only to the short run (e.g. Ilzetzki et al., 2013; Jha et al., 2014). As region-specific findings, we note also that while a cut in government consumption will have an expansionary impact in CEMAC countries.

\section{References}

Abiad, A., Furceri, D., \& Topalova, P. (2016). The Macroeconomic Effects of Public Investment: Evidence from Advanced Countries. Journal of Macroeconomics, 50, 224-40. https://doi.org/10.1016/j.jmacro.2016.07.005

Arizala, F., Gonzalez-Garcia, M. J. R., Tsangarides, M. C. G., \& Yenice, M. (2017). The Impact of Fiscal Consolidations on Growth in Sub-Saharan Africa. International Monetary Fund. https://doi.org/10.5089/9781484333112.001

Auerbach, A., \& Gorodnichenko, Y. (2013a). Fiscal Multipliers in Recession and Expansion. In A. Alesina \& F. Giavazzi (Eds.), Fiscal Policy after the Financial Crisis. Cambridge, MA: National Bureau of Economic Research. https://doi.org/10.7208/chicago/9780226018584.003.0003

Auerbach, A., \& Gorodnichenko, Y. (2013b). Measuring the Output Responses to Fiscal Policy. American Economic Journal: Economic Policy, 4(2), 1-7. https://doi.org/10.1257/pol.5.3.320

Baltagi, B. H., \& Pesaran, M. H. (2007). Heterogeneity and cross section dependence in panel data models: Theory and applications introduction. Journal of Applied Econometrics, 22(2), 229-232. https://doi.org/10.1002/jae.955

Batini, N., Eyraud, L., Forni, L., \& Weber, A. (2014). Fiscal Multipliers: Size, Determinants, and Use in Macroeconomic Projections. IMF Technical Note and Manual No. 2014/04, International Monetary Fund, Washington, DC. https://doi.org/10.5089/9781498382458.005

Baum, A., Poplawski-Ribeiro, M., \& Weber, A. (2012). Fiscal Multipliers and the State of the Economy. IMF Working Paper 12/286, International Monetary Fund, Washington, DC. https://doi.org/10.5089/9781475565829.001

Blanchard, O., \& Leigh, D. (2013). Growth Forecast Errors and Fiscal Multipliers. American Economic Review, 103(3), 117-20. https://doi.org/10.1257/aer.103.3.117

Breitung, J. (2002). Nonparametric tests for unit roots and cointegration. Journal of Econometrics, 108(2), 343-363. https://doi.org/10.1016/S0304-4076(01)00139-7

Dawood, T. C., \& Francois, J. N. (2018). Substitution between private and government consumption in African Economies. Economic Modelling, 73, 129-139. https://doi.org/10.1016/j.econmod.2018.03.012

Dell'Erba, S., Koloskova, K., \& Poplawski-Ribeiro, M. (2014). Medium-term Fiscal Multipliers during Protracted Recessions. IMF Working Paper 14/213, International Monetary Fund,Washington, DC. https://doi.org/10.5089/9781498336192.001

DeLong, J. B., \& Summers, L. H. (2012). Fiscal Policy in a Depressed Economy. Brookings Papers on Economic Activity, The Brookings Institution, Washington, DC. https://doi.org/10.1353/eca.2012.0000

Francois, J. N., \& Keinsley, A. (2019). The long-run relationship between public consumption and output in developing countries: Evidence from panel data. Economics Letters, 174, 96-99. 
https://doi.org/10.1016/j.econlet.2018.10.022

Gupta, S., Clements, B., Baldacci, E., \& Mulas-Granados, C. (2005). Fiscal Policy, Expenditure Composition, and Growth in Low-Income Countries. Journal of International, Money and Finance, 24, 441-63. https://doi.org/10.1016/j.jimonfin.2005.01.004

Herzer, D., \& Grimm, M. (2012). Does foreign aid increase private investment? Evidence from panel cointegration. Applied Economics, 44(20), 2537-2550. https://doi.org/10.1080/00036846.2011.566183

Herzer, D., \& Morrissey, O. (2013). Foreign aid and domestic output in the long run. Review of World Economics, 149(4), 723-748. https://doi.org/10.1007/s10290-013-0169-y

Ilzetzki, E., Mendoza, E., \& Vegh, C. (2013). How Big (Small?) Are Fiscal Multipliers? Journal of Monetary Economics, 60, 239-54. https://doi.org/10.1016/j.jmoneco.2012.10.011

Im, K. S., Pesaran, M. H., \& Shin, Y. (2003). Testing for unit roots in heterogeneous panels. Journal of Econometrics, 115(1), 53-74. https://doi.org/10.1016/s0304-4076 (03)00092-7

International Monetary Fund. (2018a). Regional economic outlook, Sub-Saharan Africa. Washington, DC.

International Monetary Fund. (2018b). Macroeconomic Developments and Prospects in Low-income Developing Countries. Technical report.

International Monetary Fund. (2019). Country Report No.19/2.Washington, DC.

Jha, S., Mallick, S. K., Park, D., \& Quising, P. F. (2014). Effectiveness of countercyclical fiscal policy: Evidence from developing Asia. Journal of Macroeconomics, 40, 82-98. https://doi.org/10.1016/j.jmacro.2014.02.006

MacKinnon, J. G., Haug, A. A., \& Michelis, L. (1999). Numerical distribution functions of likelihood ratio tests for cointegration. Journal of Applied Econometrics, 14(5), 563-577. https://doi.org/10.1002/(sici)1099-1255(199909/10)14:5\%3C563: aid-jae530\%3E3.3.co;2-i

Maddala, G. S., \& Wu, S. (1999). A comparative study of unit root tests with panel data and a new simple test. Oxford Bulletin of Economics and statistics, 61(S1), 631-652. https://doi.org/10.1111/1468-0084.61.s1.13

Mineshima, A., Poplawski-Ribeiro, M., \& Weber, A. (2014). Size of Fiscal Multipliers. In C. Cottarelli, P. Gerson, \& A. Senhadji (Eds.), Post-Crisis Fiscal Policy. Cambridge, MA: MIT Press. https://doi.org/10.7551/mitpress/9780262027182.003.0013

Pedroni, P. (1999). Critical values for cointegration tests in heterogeneous panels with multiple regressors. Oxford Bulletin of Economics and statistics, 61(S1), 653-670. https://doi.org/10.1111/1468-0084.0610s1653

Pedroni, P. (2001a). Fully modified OLS for heterogeneous cointegrated panels. In: Nonstationary Panels, Panel Cointegration, and Dynamic Panels (pp. 93-130). Emerald Group Publishing Limited. https://doi.org/10.1016/s0731-9053(00)15004-2

Pedroni, P. (2001a). Purchasing power parity tests in cointegrated panels. Review of Economics and Statistics, 83(4), 727-731. https://doi.org/10.1162/003465301753237803

Pesaran, M. H. (2007). A simple panel unit root test in the presence of cross-section dependence. J. Appl. Econometrics, 22(2), 265-312. https://doi.org/10.1002/jae.951

Phillips, P. C., \& Ouliaris, S. (1990). Asymptotic properties of residual based tests for cointegration. Econometrica, 58(1), 165-193. https://doi.org/10.2307/2938339

Westerlund, J. (2005). New simple tests for panel cointegration. Econometric Reviews, 24, 297-316. https://doi.org/10.1080/07474930500243019

\section{Notes}

Note 1. See e.g. Arizala et al. (2017) and Mallick (2006) for studies focusing on the short to medium-term analysis.

Note 2. The $\chi^{2}$ value is based on MacKinnon et al. (1999) p-values for Johansen's cointegration trace test.

\section{Copyrights}

Copyright for this article is retained by the author(s), with first publication rights granted to the journal.

This is an open-access article distributed under the terms and conditions of the Creative Commons Attribution license (http://creativecommons.org/licenses/by/4.0/). 